\title{
Estudio comparativo del uso de la matriz ósea desmineralizada de origen humana y de la poliuretana derivada del aceite de mamona sobre el proceso de regeneración ósea. Estudio histométrico en calota de conejos
}

\author{
A comparative study on the use of demineralized bone matrix of human \\ origin and polyurethane derived from castor oil in bone regeneration \\ processes. A histometric study on rabbit calvaria
}

\author{
J. Rodrigues Laureano Filho', M. Allais², P. Edward Maurette', J.R. Albergaria Barbosa ${ }^{3}$
}

\begin{abstract}
Resumen: Objetivo. Analizar histométricamente el efecto de la matriz ósea desmineralizada de origen humana y de la resina poliuretana derivada del aceite de mamona, sobre el proceso de regeneración ósea. Diseño del estudio: fueron utilizados 24 conejos y en cada calota craniana fueron preparadas dos cavidades quirúrgicas, siendo una a cada lado de la sutura parietal. Los animales fueron divididos en dos grupos. En el grupo I la cavidad experimental (lado derecho) fue rellenada con la poliuretana derivada del aceite de mamona, mientras que en el grupo II la cavidad experimental fue rellenada con la matriz ósea desmineralizada de origen humano. Las cavidades de control fueron rellenadas solo con la sangre del animal. Los animales fueron sacrificados en los períodos postoperatorios de 04, 07 y 15 semanas. Resultados. El análisis estadístico, realizado en base de los datos de la histometría, mostró una mayor neoformación ósea de los grupos I y II en relación al grupo control, no existiendo diferencia estadística cuando los grupos experimentales fueron comparados. Conclusiones. El uso de poliuretana derivada del aceite de mamona y matriz ósea desmineralizada de origen humano mejoran el proceso de regeneración cuando lo comparamos a la regeneración ósea normal resultando que entre ambos materiales tuvieron un comportamiento similar sin diferencias estadísticas significantes entre sí.
\end{abstract}

Palabras clave: Matriz ósea; Regeneración ósea; Polímero de mamona.

Recibido: 18.04 .06

Aceptado: 01.06 .07

\begin{abstract}
Objective. The present study was aimed at carrying out a histological and histometric analysis on the effect of human demineralized bone matrix and a polyurethane resin, derived of the castor bean oil, on the bone regeneration process. Design: For this, 24 rabbits were used and in each calvarium two surgical bone defect were prepared, one on the right side and another on the left side of the parietal suture. The animals were divided into two groups. In group I the experimental defect (right side) was filled with polyurethane derived from oil of the castor oil plant, while in group II the experimental cavity was filled with demineralized bone matrix of human origin. The control cavities were just filled with the blood of the animal. The animals were sacrificed in the postoperative period at 04, 07 and 15 weeks. Results. The statistical analysis, which was based on the data of the histometric study, showed larger bone neoformation in groups I and II in relation to the control groups, and there were no statistical differences when the experimental groups were compared. Conclusions. The use of polyurethane resin implants and demineralized human bone matrix helped and optimized the regeneration process when compared with natural bone regeneration, and similar behavior was obtained without statistical differences in both materials.
\end{abstract}

Key words: Bone matrix; Bone regeneration; Polyurethane resin implant.

1 Odontólogo, PhD en Cirugía y Traumatología Buco Maxilofacial. Profesor Asociado del Área de Cirugía y Traumatología Buco Maxilofacial de la Universidad de Pernambuco. Facultad de Odontología de Pernambuco. FOP-UPE. Recife - PE - Brasil.

2 Odontólogo USM. Caracas -Venezuela. MSc en Cirugía y Traumatología Buco-Maxilofacial de la Facultad de Odontología de Piracicaba. Universidad Estadual de Campinas (FOP-Unicamp). Piracicaba-SP-Brasil. Doctorando en Cirugía y Traumatología Buco-Maxilofacial de la Facultad de Odontología de Pernambuco. Universidad de Pernambuco (FOP-UPE). Recife-PE-Brasil.

3 Odontólogo, Cirujano Buco-Maxilofacial. Profesor Adjunto. Área de Cirugía y Traumatología Buco-Maxilofacial de la Facultad de Odontología de Piracicaba. Universidad Estadual de Campinas (FOP-Unicamp). Piracicaba-SP-Brasil.

\section{Correspondencia:}

José Rodrigues Laureano Filho

Facultad de Odontología de Pernambuco - UPE

Área de Cirugía Buco Maxilofacial

Av. Gal Newton Cavalcanti, N 1650, 


\section{Introducción}

El hueso es un tejido conjuntivo extremadamente duro y con gran plasticidad, presentando un metabolismo altamente complejo, con potencial de reparación envolviendo iones, células, hormonas, proteínas y factores nutricionales. El tejido óseo posee una alta capacidad de reparación espontánea cuando es lesionado, reponiendo después de un breve intervalo de tiempo, toda la partes perdida. ${ }^{1}$ Entre tanto, existen algunos casos en que los defectos son extensos y no tienen la capacidad de repararse espontáneamente, por lo que es necesario utilizar diversas técnicas quirúrgicas en la tentativa de reparación de la deficiencia ósea. ${ }^{2}$

La reconstrucción de estas lesiones amplias en tejidos duros siempre fue uno de los grandes desafíos para la ciencia, siendo utilizados para tal fin hueso autógeno, homógeno, liofilizado, desmineralizado, así como materiales artificiales o sintéticos. ${ }^{2}$

Los injertos óseos desmineralizados y liofilizados promueven una rápida cicatrización de los defectos óseos y poseen la propiedad de inducir una considerable formación ósea, además de no presentar ningún poder antigénico. ${ }^{3}$ Estos injertos tienen como desventaja su forma y su origen. El tamaño de sus partículas limita la cantidad de aposición coronal del hueso disponible en defectos horizontales y cualquier presión leve del tejido puede desplazar el material injertado. ${ }^{4}$ Un gran problema en las reconstrucciones óseas es la dificultad de obtención de hueso humano viable en grandes cantidades, asociado a la prohibición en varios países de la comercialización de órganos o tejidos humanos y de la posibilidad de transmisión de enfermedades, así como su alto costo. ${ }^{1}$

En 1984, el grupo de Química Analítica y Tecnología de Polímeros de la Escuela de Ingeniería de São Carlos, SP - Brasil, desarrolló una resina poliuretana de origen vegetal extraída del aceite de la mamona. ${ }^{5}$ Los polímeros poliuretanos tienen como ventajas el proceso y la flexibilidad de formulación, excelentes propiedades estructurales, ausencia de emisión de irritantes o vapores tóxicos, además de la biocompatibilidad. ${ }^{6}$ Henning y cols. ${ }^{7}$ en 1989 observaron la biocalcificación in vivo e in vitro de las resinas poliuretanas. En 1997, Carvalho y cols. ${ }^{8}$ observaron la oseointegración de este polímero y relataron la reabsorción y la substitución del polímero por tejido óseo.

Los estudios afirman que el hueso autógeno es el mejor material para injertar, ${ }^{9}$ pero varios sustitutos de tejido óseo han sido propuestos para evitar la morbilidad del sitio donante y el aumento del tiempo operatorio, ${ }^{10}$ buscando crear o extraer de la naturaleza materiales que promuevan el incremento de la reparación y neoformación ósea, siendo biocompatibles, osteocondutores y osteoindutores. ${ }^{11}$

\section{Material y método}

\section{Animales y anestesia}

En el presente estudio fueron utilizados 24 conejos albinos de la raza Nueva Zelanda, hembras, con edad comprendida entre 3 y 6 meses, y peso medio de 2,9 kg. Los animales fueron mantenidos en jaulas en el Animalario de la Facultad de Odontología de

\section{Introduction}

Bone is connective tissue that is extremely hard and it has great plasticity and extremely complex metabolism, with a repair potential that involves ions, cells, hormones, proteins and nutritional factors. Bone tissue has a high capacity for spontaneous repair when harmed, and the portion lost is replaced after a very brief period of time.? There are some cases in which the defects are extensive, and they do not have the capacity for spontaneous repair. As a result, a variety of surgical techniques have to be used in an effort to repair the osseous deficiency. ${ }^{2}$

The reconstruction of these large lesions in hard tissue was always one of the great challenges for science, and autogenous, homogenous, lyophilized, and demineralized bone was used for this, as well as artificial or synthetic material. ${ }^{2}$

Demineralized and lyophilized bone grafts promote fast healing of bone defects, and they are able to induce considerable bone formation, in addition to not having any antigenic potential. ${ }^{3}$ The disadvantages of these grafts are their shape and their origin. The particle size limits the quantity of coronal apposition of the bone available in horizontal defects, and any slight pressure of the tissue can dislocate the grafted material. ${ }^{4} \mathrm{~A}$ large problem with bone reconstruction is the difficulty of obtaining viable human bone in large quantities, together with the prohibition in various countries of human organs or tissue trade and of the possibility of disease transmission, as well as the elevated cost.

In 1984, the group Analytical Chemistry and Polymer technology from the School of Engineering of São Carlos, SP - Brasil, developed a polyurethane resin with a vegetable origin extracted from castor bean oil.5 Polyurethane polymers have advantages as to processing and formula flexibility, they have excellent structural properties, absence any emission of irritants or toxic vapors, in addition to biocompatibility. 6 Henning et al.? observed in 1989 the biocalcification in vivo and in vitro of polyurethane resins. In 1997, Carvalho et al..$^{8}$ observed osseointegration of this polymer, and they reported the resorption and the substitution of the polymer by bone tissue.

The studies state that autogenous bone is the best grafting material, 9 but various bone tissue substitutes have been proposed in order to avoid morbidity of the donor site and the increase in operating time. ${ }^{10}$ The aim is to create or extract from nature, materials that encourage bone repair and the formation of new bone, and that are biocompatible, osteoconductive and osseoinductive. ${ }^{11}$

\section{Material and method}

Animals and anesthesia

In this study 24 female albino rabbits, New Zealand breed, were used that were between 3 and 6 months, with 
Piracicaba - Unicamp, durante el período experimental, con dieta sólida y agua sin restricción, a temperatura ambiente. Estos animales fueron divididos en dos grupos iguales (Grupo I y Grupo II) experimental.

El día anterior a la cirugía todos los animales fueron sometidos a tricotomía del pelo de la cabeza, pesados y los cálculos referentes al volumen anestésico fueron realizados para cada animal.

Para la aplicación de la anestesia general fue utilizada atropina $0,15 \mathrm{ml} / \mathrm{kg}$ de peso, por vía subcutánea, cinco minutos antes de la anestesia propiamente dicha para evitar la bradicardia provocada por el anestésico. Ketamina (Francotar ${ }^{\circledR}$ - Virbac do Brasil Industria y Comércio Ltda. - São Paulo.) y solución acuosa a 2\% de Clorhidrato de 2-(2,6-xilidino)-5,6-dihidro-4-H-1,3-tiazin (Rompum ${ }^{\circledR}$ Bayer SA - Saúde Animal ) fueron aplicados en una concentración de $0,5 \mathrm{ml} / \mathrm{Kg}$ de peso, por vía intramuscular profunda.

\section{Procedimiento quirúrgico}

Los procedimientos operatorios experimentales fueron realizados bajo condiciones asépticas utilizándose instrumental estéril y campos deshechables. Después de realizada la tricotomía de la calota fue realizada la antisepsia con solución alcohólica de polivilpirrolidona yodo a $10 \%$ y posteriormente el aislamiento del área a ser operada con campos estériles.

El procedimiento quirúrgico fue dirigido a través del protocolo descrito por Alberius y cols.(1989); ${ }^{12}$ Alberius y cols.(1990); ${ }^{13}$ La piel y el tejido subcutáneo fueron seccionados a través de una incisión paramediana en la calota del conejo, realizada con lamina de bisturí $n^{\circ} 15$, extendiéndose desde el hueso nasal hasta el frontal. El periostio que recubre la región frontal y la sutura coronal fue incidido, elevado y desplazado lateralmente (Fig. 1A). Dos cavidades óseas circulares, fueron producidas en la región parietal bilateralmente, utilizándose una fresa de trefina con $10 \mathrm{~mm}$ de diámetro, acoplada a un contra-ángulo reductor 16:1, montada en baja rotación en un motor eléctrico, con cuidado de no perforar el seno sagital y/o la duramadre (Figs. 1B y $1 \mathrm{C}$ ).

Durante las perforaciones óseas, el procedimiento fue realizado bajo constante irrigación con solución fisiológica de cloreto de sodio $0,9 \%$ evitándose así el sobrecalentamiento del hueso. Después de la realización de las perforaciones, el tapón óseo confeccionado por de la trefina fue delicadamente retirado con la ayuda de un periostomo (Fig. 1D). Siempre la cavidad del lado derecho fue rellenada por el material a ser estudiado y la del lado izquierdo dejada vacía (Fig. 1E). Las cavidades del hueso parietal derecho del Grupo I fueron rellenadas con hueso desmineralizado de origen humano (DEMBONE TM - Pacific Coast Tissue Bank ) (Fig. 1F) y las cavidades del lado izquierdo fueron rellenadas por sangre, sirviendo como control. La cavidad del parietal derecho de los conejos del Grupo II fue rellenada con AUG-EX (AUG-EX ${ }^{\circledR}$-Poliquil-Araraquara-São Paulo ) (Fig. 1G), una resina poliuretana extraída del óleo de la mamona, y la cavidad del parietal izquierdo también fue rellenada con sangre, como control de este grupo. Posteriormente, el perióstio fue reposicionado y los planos superficiales suturados con nylon número 4.0 (Ethicon ${ }^{\circledR}$ - Nylon4-0. Johnson \& Johnson - São José dos Campos/SP - Brasil). a mean weight of $2.9 \mathrm{~kg}$. The animals were kept in cages in the animal-breeding laboratory of the Dental Faculty of Piracicaba - Unicamp, during the duration of the experiment, with unrestricted solid food and water, and at room temperature. The animals were divided into two similar experimental groups (Group I and Group II).

The day before the surgery all the animals underwent trichotomy of head hair. They were weighed and the anesthesia required for each animal was calculated.

Atropine $0.15 \mathrm{ml} / \mathrm{kg}$ weight was used for applying general subcutaneous anesthesia, which was administered five minutes before the anesthesia itself in order to avoid the bradycardia produced by the anesthetic. Ketamina (Francotar $^{\circledast}$ - Virbac do Brasil Industria y Comércio Ltda. - São Paulo.) and an aqueous solution of 2\% Chlorhydrate of 2(2,6-xylidine)-5,6-dihydro-4-H-1,3-tiazine (Rompum ${ }^{\circledast}$ Bayer S.A - Saúde Animal) was applied at a concentration of $0.5 \mathrm{ml} / \mathrm{kg}$ weight, using deep intramuscular administration.

\section{Surgical procedure}

The experimental operative procedures were carried out under aseptic conditions using sterile instruments and disposable drapes. After carrying out a trichotomy of the calvarium, antisepsis was carried out with an alcoholic solution containing polyvinylpyrrolidone iodine at $10 \%$. The area to be operated was then isolated using sterile drapes.

The surgical procedure was carried out following the protocol described by Alberius et al.(1989); ${ }^{22}$ Alberius et al. (1990). ${ }^{13}$ The skin and subcutaneous tissue were sectioned by means of a paramedian incision into the calvarium of the rabbit, which was carried out using a bistoury with a $\mathrm{N}^{0} 15$ blade, that was extended from the nasal to the frontal bone. The periosteum that covered the frontal region and the coronal suture were incised, elevated and pulled sideways (Fig. 1A). Two circular bone cavities were made in the parietal region bilaterally, using a trephine drill with a $10 \mathrm{~mm}$ diameter, that was attached to 16:1 reducer of contra angle that was mounted with care on low rotation in an electric motor so as not to perforate the sagittal sinus and/or dura mater (Fig. $1 B$ and $1 C$ ).

The bone perforation procedure was carried out under constant irrigation with a physiological solution of sodium chloride of $0.9 \%$, so that overheating of the bone was avoided. After the perforations were carried out, the bone disc made by the trephine was delicately removed with the help of an elevator lever (Fig. 1D). The cavity on the right side was always filled by the material under study, and the left side was left empty (Fig. 1E). The parietal bone cavities on the right side of Group 1 were filled with demineralized bone of human origin (Dembone TM - Pacific Coast Tissue Bank) (Fig. 1F) and the cavities on the left side were filled with blood as a control. The parietal bone cavities on the right side of 

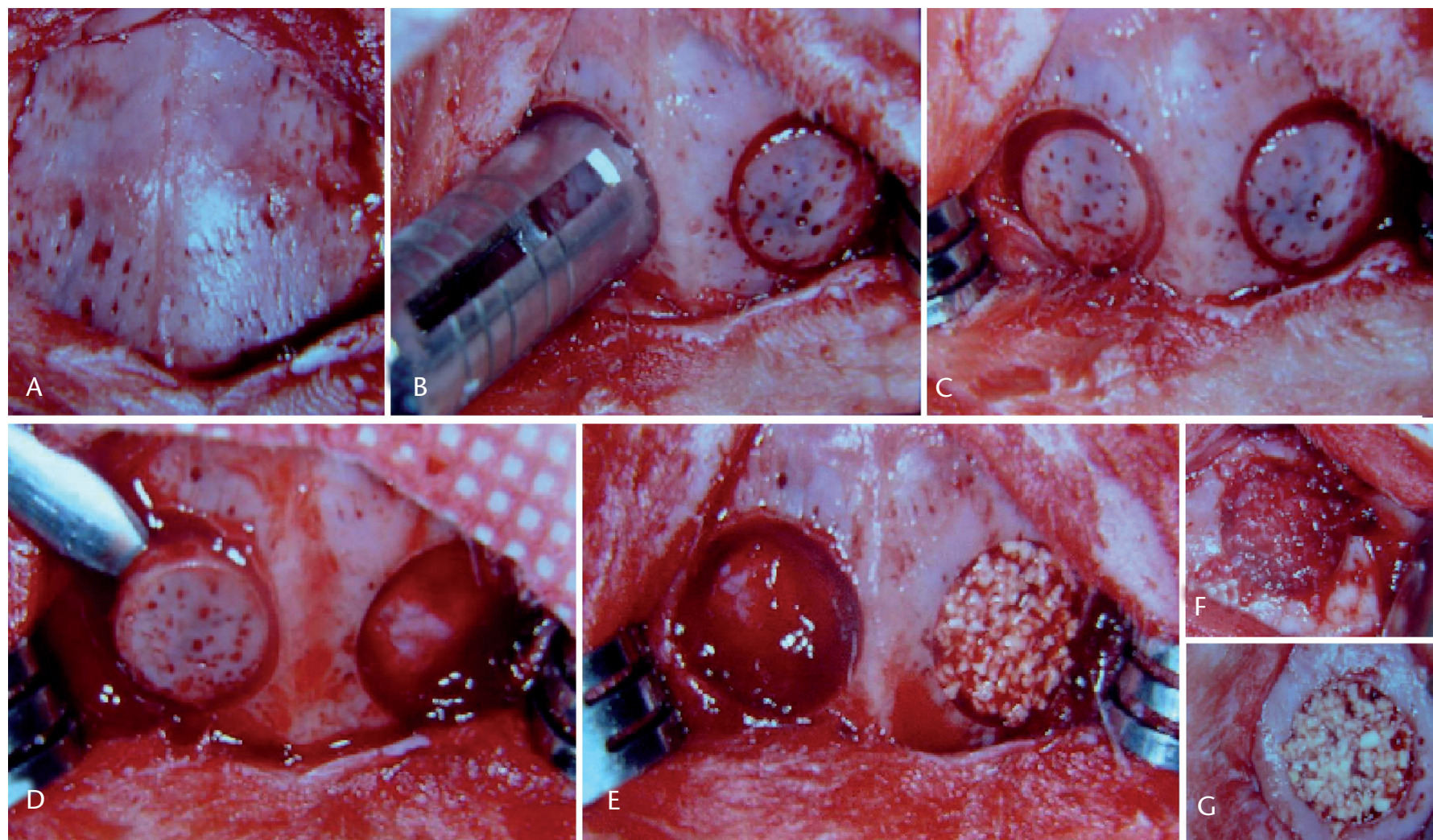

Figura 1. A) Calota craneana. B) Perforación de las cavidades con la fresa de trefina. C) Las cavidades osteotomizadas. D) Remoción cuidadosa del tapón óseo. E) Cavidad rellenada con sangre en al lado izquierdo y con el material testado en el lado derecho. F) Hueso desmineralizado rellenando una de las cavidades. G) Polímero de mamona rellenando una cavidad.

Figure 1. A) Cranial calvaria. B) Perforation of cavities with trephine drill. C) Osteotomized cavities. D) Careful removal of bone disc. E) Cavity filled with blood on left side and with the tested material on right side. F) Demineralized bone filling one of the cavities. G) Castor bean polymer filling cavity.

Todos los animales recibieron Penicilina Benzatina en dosis única de 1,0 ml, por vía intraperitoneal, siguiendo las recomendaciones del fabricante. En cada animal operado fue realizada una aplicación tópica de solución alcohólica de polivilpirrolidona yodo a $10 \%$, como medida antiséptica local en el postoperatório inmediato. Los animales permanecieron en observación en el período inicial de la recuperación anestésica y en seguida fueron llevados a sus jaulas y mantenidos hasta el momento del sacrificio.

Los animales fueron sacrificados en los períodos de 04, 07 y 15 semanas de postoperatorio, con un total de cuatro animales de cada grupo, por período de sacrificio. Fue utilizada una sobredosis de la mezcla anestésica conteniendo Francotar y Rompum, para el sacrificio de los animales. Después de ésto, se realizo la retirada de los bloques óseos conteniendo las cavidades óseas del estudio.

\section{Estudio histométrico}

Para la realización del análisis histométrico lineal fueron utilizados un microscópio óptico con objetivo para aumento de 4/0,1, una filmadora, una computadora y un programa para análisis de las imagenes (Kontron eletronik - Imaging System KS 400). Los cortes histológicos de los especímenes obtenidos de los animales de todos los grupos, teñidos con H\&E fueron observados a través the rabbits in Group II were filled with AUG-EX (AUG - EX®Poliquil - Araraquara - São Paulo) (Fig. 1G), a polyurethane resin extracted from castor bean oil, and the parietal bone cavity on the left side was also filled with blood, as a control for this group. Later the periosteum was repositioned and the superficial tissues were sutured with number 4.0 nylon (ETHICON ${ }^{\circledR}$ - Nylon 4-0 . Johnson \& Johnson - São José dos Campos/SP. - Brasil).

All the animals were given a single dose of intraperitoneal Benzathine Penicillin of $1.0 \mathrm{ml}$, following the recommendations of the manufacturer. An alcoholic solution of polyvinylpyrrolidone iodine at $10 \%$ was given topically to all the animals that were operated as a local antiseptic measure during the immediate postoperative period. The animals remained under observation for the initial anesthesia recovery period and they were immediately taken to their cages where they were kept until sacrificed.

The animals were sacrificed at 4,7 and 15 weeks into the postoperative period. There were a total of four animals in each group, per sacrificial period. An overdose of anesthesia containing Francotar and Rompum was used to sacrifice the animals. After this, the bone blocks containing the bone cavities in the study were removed. 
del analizador de imágenes Kontron Elektronik - KS 400 - 2.0, da Zeiss.

Las imágenes histológicas seleccionadas fueron capturadas por el ordenador a través de la cámara. Para que esto fuese posible, fue establecido un "macro", o sea, un conjunto de funciones que permitieron ejecutar automáticamente la selección de las imágenes, la definición de las condiciones de la morfometría y la ejecución de la medida, a través del analizador de imágenes.

Cada lámina histológica fue focalizada en objetivas de $1 \mathrm{X}$, y la imagen fue captada por el sistema y visualizada on line no display, que realizó la normalización y congelamiento de esta, pudiendo entonces ser debidamente medida. Siendo, entonces, sobrepuesto a ellas un retículo de 100 pontos, también denominado grada de intersecciones, donde cada punto corresponde a $300 \times 300 \mu \mathrm{m}$, lo que equivale a $1,2 \mathrm{~mm}^{3}$, por tanto, el volumen total del retículo era de $120 \mathrm{~mm}^{3}$. El sistema empleado para el análisis histométrico fue por el contaje de puntos de forma manual que recaían sobre el hueso neoformado en las áreas de intersección de las líneas horizontales y verticales del retículo.

La evaluación de los datos se realizo a través do data list, una lista de resultados morfométricos. Para cada campo medido esa lista de resultados era transferida para el programa Excel, formando el banco de datos de cada animal.

Para establecer el número de puntos a ser contados en cada grupo, en los tres períodos postoperatorios, con un sistema de 100 puntos, se utilizo la fórmula propuesta para error padrón relativo:

$$
\begin{aligned}
& E P R=\sqrt{\frac{(1-V v)}{n}} \\
& E P R=\text { error padrón relativo } \\
& V v=\text { densidad de volumen de la estructura en análisis } \\
& \mathrm{n}=\text { número de puntos a ser contados }
\end{aligned}
$$

Para las condiciones de trabajo la densidad de volumen $(\mathrm{Vv})$, o sea la fracción de volumen ocupada por un objeto en una determinada estructura fue igual a $100 \%$. En bioestadística es aceptable el índice de significancia de 0,05 (probabilidad igual a 95\%), por eso fue atribuido ese valor a EPR. De esa forma:

$$
\begin{aligned}
& 0,05=\sqrt{\frac{(1-10)}{n}} \quad \frac{9}{n} \\
& 0,0025=n=3600 \\
& n_{\text {corregido }}=\frac{3600}{10}=360
\end{aligned}
$$

Por sorteo fueron escogidas cinco laminas de cada grupo, en los períodos de sacrificios (4, 7 y 15 semanas). Todas las láminas seleccionadas contenían cortes histológicos semi-seriados con 6ìm de espesor. Fueron analizados por toda la extensión del defecto, donde habían 360 puntos para cada grupo en los diferentes períodos de sacrificio. Para la contabilización de los puntos, fue evaluado solamente los lugares donde hubo presencia de tejido óseo neoformado.
Histometric study

An optic microscope was used for carrying out the histometric linear analysis that had a 4/0,1, lens, video camera, computer and program for image analysis (Kontron Eletronik - Imaging System KS 400). The histological slices of the specimen obtained from all the animals in the groups that were colored with $H \& E$, were observed through the image analyzer Kontron Elektronik - KS 400 - 2.0, da Zeiss.

The histological images selected were captured by the computer through the video camera. In order for this to be possible, a "macro" was established, or rather, a group of functions that allowed carrying out automatically the image selection, the definition of the morphometric conditions and the measurement execution through the image analyzer.

Each histological section was focused with a $1 X$ lens, and the image was captured by the system and viewed on line, not display. The normalization and freezing was in this way carried out so that the section could then be properly measured. A100 point reticle was superimposed, also called an intersection grade, where each point corresponds to $300 x$

$300 \mu \mathrm{m}$, which is the equivalent of $1.2 \mathrm{~mm}^{3}$. Therefore, the total volume of the reticule was $120 \mathrm{~mm}^{3}$. The system used for the histometric analysis was through counting the points manually that fell on the newly formed bone in the intersection areas of the horizontal and vertical lines of the reticle.

The evaluation of the data was carried out through a data list, which is a list of morphometric results. For every field measured, the list of results was transferred to the Excel program, making up the database of each animal.

In order to establish the number of points to be counted in each group, in the three postoperative periods, using a 100 point system, the formula suggested for relative pattern error was used:

$$
\begin{aligned}
& \mathrm{RPE}=\sqrt{\frac{(1-V v)}{\mathrm{n}}} \\
& \mathrm{RPE}=\text { relative pattern error } \\
& \mathrm{V} \mathrm{v}=\text { volume density of structure under analysis } \\
& \mathrm{n}=\text { number of points to be counted }
\end{aligned}
$$

With regard to the working conditions, volume density $(V v)$, or the fraction of volume occupied by an object in a certain structure, was equal to $100 \%$. In biostatistics a significance index of - of 0.05 (probability equal to $95 \%$ ) is acceptable, and for this reason the RPE was attributed with this value. In this way:

$$
\begin{aligned}
& 0,05=\sqrt{\frac{(1-10)}{n}} \quad \frac{9}{n} \\
& 0,0025=n=3600 \\
& n_{\text {corrected }}=\frac{3600}{10}=360
\end{aligned}
$$




\section{Resultados}

El estudio de las suposiciones reveló que ningún dato fue violado y que el análisis de variancia fue ejecutado sin la necesidad de correcciones en los datos.

En el cuadro de análisis de variancia, se observa que solamente hay efecto significativo del material. No hay indicios que afirmen que exista efecto significativo del tiempo o de la interacción entre los tiempos y los materiales.

A través de este resultado, se procedió a la comparación de medias de los materiales a través del test de Tukey.

\section{Comparación de medias de los mmateriales}

En la tabla 2 se observa que hay fuertes indicios de diferencia entre las medias verdaderas del tratamiento control y de los otros dos grupos. La figura 2 muestra la comparación entre las medias de formación de hueso obtenidas de los materiales.

\section{Discusión}

El interés en estudiar materiales capaces de sustituir el tejido óseo ha aumentado en las profesiones que componen el área de la salud, ${ }^{14}$ principalmente en la odontología, donde la aparición de tratamientos reconstructivos como los implantes oseointegrados y una mayor concienciación de la importancia de la reconstrucción ósea en los pacientes sometidos a procedimientos mutiladores, ha llevado la necesidad de reponer ese tejido óseo perdido con mayor frecuencia que anteriormente. ${ }^{15}$

El injerto óseo autógeno hasta ahora es considerado el mejor substituto óseo en defectos críticos, pero a pesar de sus ventajas,
Tabla 1. Cuadro de análisis de variancia para estudio de los factores tiempo y materiales sobre la formación de hueso

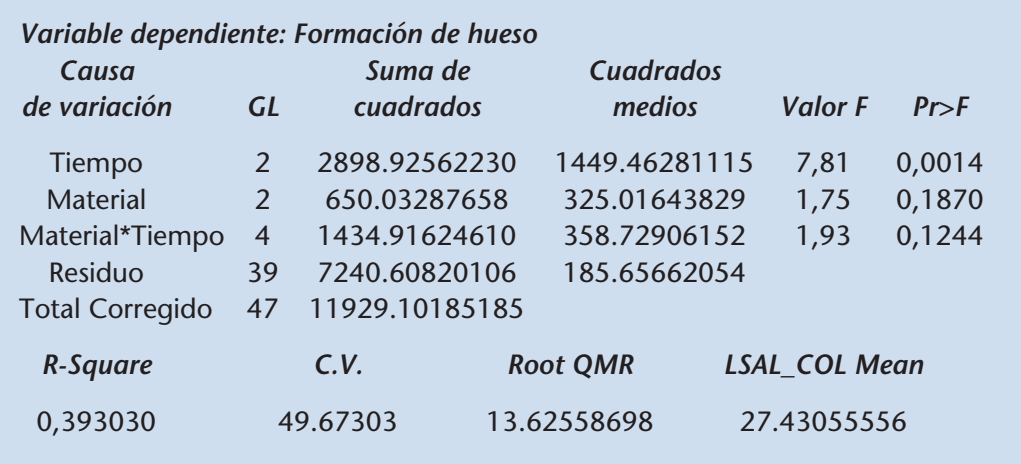

Table 1. Analytical table showing study variance regarding time and material factors on bone formation

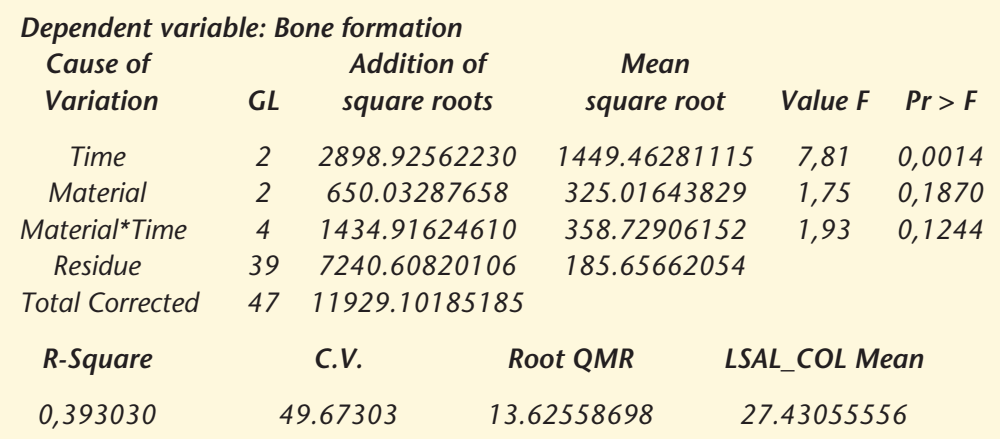

Tabla 2. Medias y desvíos padrón de los dados originales (no transformados) y resultado del test de Tukey con nivel de significancia de $5 \%$ presentando letras iguales al lado de medias de materiales que no difieren significativamente entre si

$\begin{array}{cccc}\text { Material } & \text { Número de observaciones } & \text { Media } & \text { Desvio padrón } \\ \text { Aug-Ex } & 12 & 35,1667 & 18,0613 \\ \text { Dembone } & 12 & 34,2222 & 11,9893 \\ \text { Control } & 24 & 19,1667 & 12,9563\end{array}$

Table 2. Measurements and deviation pattern of original data (not transformed) and Tukey test results with a significance level of 5\% showing letters that are the same next to the material measurements that do no differ significantly among themselves

$\begin{array}{cccc}\text { Material } & \text { Number of observations } & \text { Average } & \text { Deviation Pattern } \\ \text { Aug-Ex } & 12 & 35,1667 & 18,0613 \\ \text { Dembone } & 12 & 34,2222 & 11,9893 \\ \text { Control } & 24 & 19,1667 & 12,9563\end{array}$

Five sections were selected in each group on a draw basis, at the time of sacrifice. (4, 7 and 15 weeks). All the sections selected contained semi-serial histological slices with a thickness of bim. These were analyzed throughout the whole defect, where there were 360 points for each group in the different sacrifice times. Only the areas where there was newly formed bone were the points tabulated.

\section{Results}

The supposition study revealed that no data were violated and that the variance analysis was executed without the need for data correction.

In the variance analysis pattern, it was observed that only material had a significant effect. There were no signs to confirm that time had any significant effect or that there was any interaction between time and materials.

Through these results, the measurements of the materials were compared through the Tukey test.

\section{Comparison of the material measurements}

In table 2, strong signs can be observed of a difference existing between the true measurements of the control treatment and the other two groups. Figure 2 shows the comparison between the mean bone formation obtained with the materials. 
existen algunas desventajas que siguen causando problemas, tales como la mayor morbilidad y el ser un recurso capaz de agotarse, motivando de esta forma a diversas especialidades medico-odontológicas a procurar substitutos óseos a la altura, que posean las ventajas y minimizándose las desventajas. ${ }^{16}$ El mercado dispone de sustancias comercialmente consolidadas y algunas todavía en fase de prueba, que han sido usadas como sustitutos óseos efectivos, con algunas propiedades esperadas, tales como: biocompatibilidad, osteoconducción, osteoinducción y reabsorción. ${ }^{2}$

Entre los sustitutos óseos derivados del tejido óseo, optamos por utilizar el hueso desmineralizado de origen humano por ser uno de los mas utilizados en la odontología, por ser homógeno, ${ }^{17}$ y uno de los pocos, en esta categoría, disponibles comercialmente, además de presentar buenos resultados reconocidos científicamente. 9,18 La propiedad discutible del hueso desmineralizado de origen humano de promover la osteoinducción, es un dato importante para que lo utilizáramos en esta investigación. ${ }^{9}$

Otra categoría de substitutos óseos es la compuesta por los no derivados del tejido óseo, como las cerámicas (hidroxiapatita, tricálcio-fosfato), vidrio bioactivo, sulfato de calcio y los polímeros, entre otros. Estos biomateriales son materiales sintéticos desarrollados con el objetivo de estimular y promover la reparación ósea, evitando la utilización del injerto o por lo menos minimizando su uso. ${ }^{14}$ En esta categoría destacamos los biopolímeros por presentar, en los últimos años, una gran evolución científica. ${ }^{18}$ Entre los biomateriales encontramos la poliuretana derivada del aceite de la mamona, que fue utilizada en este estudio, por encontrar su desarrollo total a nivel nacional, por ser de origen vegetal y de bajo coste, ${ }^{14}$ así como también por presentar pruebas científicas de biocompatibilidad, ${ }^{23}$ y potencial de osteoconducción. ${ }^{14,18}$

Con el intento de evaluar los diferentes materiales que vienen siendo desarrollados para ayudar en la reparación ósea, varios métodos de pesquisa son utilizados. Según Frame, ${ }^{19}$ en 1980, un modelo animal ideal para la investigación de injertos óseos debe ser barato, de fácil disponibilidad y manipulación, así como presentar una región adecuada con hueso cortical y esponjoso que permita la preparación de cavidades óseas de tamaño suficiente para la investigación. En 1980 Frame, ${ }^{19}$ confirmo que la calota craneal de los conejos es una excelente región para realizar estudios de substitutos óseos que serán utilizados en los maxilares, debido a la semejanza que existen entre los huesos cranianos de los conejos y los maxilares de los humanos. Embriológicamente tienen el mismo origen, intramembranoso, morfológicamente, se encuentran formados por dos corticales separadas por hueso medular y fisiológicamente presentan el mismo patrón de reparación. ${ }^{19}$ Kramer y cols. ${ }^{20}$ (1968),

\section{Discussion}

The interest in studying materials that are able to substitute bone tissue has increased among the professionals in this health area, ${ }^{14}$ principally in dentistry where the appearance of reconstructive treatments with osseointegrated implants, and a greater awareness of the importance of bone reconstruction in patients subjected to mutilating procedures, has led to the need for replacing lost bone tissue, now more than ever. ${ }^{15}$

Autogenous bone grafts have, up until now, been considered the best bone substitute for critical defects but, in spite of these advantages, there are some disadvantages that continue causing problems such as greater morbidity and the supply source may run out. This has motivated the different medical-dental specialties to procure bone substitutes of this level with these advantages, but with minimal disadvantages. ${ }^{16}$ The market has commercially consolidated substances, and some that are still being tested, which have been used as effective bone substitutes, with some expected properties such as biocompatibility, osteoconduction, osteoinduction and resoption. ${ }^{2}$

Of the bone substitutes derived from bone tissue, we opted to use demineralized bone of human origin as this is one of the most used in dentistry as it is homogenous. ${ }^{17}$ It is also one of the very few substitutes that is commercially available in this category, and it has also shown good results that have been recognized scientifically.9,18 The most arguable property of demineralized bone of human origin is that of encouraging osteoinduction, and it was because of this important property that it was used in our investigation. ${ }^{9}$

Another category of bone substitutes is made up of those that are not derived from bone tissue, such as ceramics, (hydroxyapatite, tricalcium-phosphate), bioactive glass, calcium sulphate, and polymers, among others. These biomaterials are synthetic materials that have been developed with the aim of stimulating and encouraging bone repair, avoiding the use of a grafts or at least minimizing their use. ${ }^{14}$ Within this category biopolymers should be highlighted, as over the last few years they have undergone considerable scientific advances. ${ }^{18}$ Among the biomaterials we have polyurethane derived from castor bean oil, which was used in this investigation because it is completely developed in this country, because it has a vegetable origin, and because 
demostraron que, la principal fuente de células osteogénicas es el tejido óseo de los márgenes del defecto, hecho que capacita a la calota de los conejos, ya que la interferencia del perióstio es menor que en otras regiones tanto del conejo como de otros animales.

La utilización de defectos críticos (aquellos donde la reparación ósea espontánea no es capaz de rellenar el defecto en su totalidad con tejido óseo) en los modelos de estudio de injertos óseos tiene una importancia relevante, ya que cualquier neoformación de tejido óseo que ocurra puede ser atribuida al material que fue utilizado para su relleno. ${ }^{1,19}$ Un estudio completo realizado por Frame, ${ }^{19}$ en 1980, evaluó diversos diámetros en la calota craniana de conejos de la raza New Zealand y observó que las cavidades no presentaron reparación ósea cuando éstas eran mayores de $15 \mathrm{~mm}$ de diámetro; en este trabajo fueron confeccionadas cavidades de $10 \mathrm{~mm}$ de diámetro, tamaño considerado inferior al crítico, pero solo de esta forma sería capaz de realizar dos cavidades en la misma calota una para el grupo experimental y otra para el grupo control; cabe destacar que los diversos períodos de sacrificio (4, 7 e 15 semanas) permiten evaluar la regeneración ósea igual que si al final ocurriese reparación completa. Otra justificativa para el diámetro utilizado es que el objetivo principal del trabajo fue comparar la regeneración entre dos sustitutos óseos, y no la regeneración ósea natural de la calota del conejo.

Los resultados demostraron que al final del mayor período para el sacrificio, que eran 15 semanas, la reparación ósea espontánea no fue suficiente para promover la regeneración ósea completa entre los bordes de las cavidades control. Esto confirma los resultados de diversos autores que concuerdan que si el defecto crítico no recibe un tratamiento específico, sino que se permite la regeneración espontánea éste no tendrá una completa reparación ósea.10,22 Con ésto, la reparación ósea encontrada en las cavidades experimentales de este trabajo puede ser relacionada al relleno de las cavidades con la matriz ósea desmineralizada y es polímero de mamona. A pesar de que las cavidades utilizadas no son consideradas defectos óseos críticos, éstas presentaban un diámetro que permitió evaluar la capacidad de reparación de los sustitutos óseos utilizados.

De forma general, observamos a través del análisis histológico, que los materiales utilizados influenciaron positivamente en la neoformación ósea de los defectos mejorándola en calidad y cantidad, cuando comparadas con el grupo control. En ambos grupos experimentales la osteoconducción fue la vía responsable para la reparación. El hueso desmineralizado presentó un comportamiento semejante al encontrado por otros autores en diferentes trabajos. ${ }^{1,23}$

Con el objetivo de proporcionar una mayor comparación entre los materiales de estudio, utilizamos un análisis histométrico que es capaz de cuantificar la neoformación ósea.24,25

El análisis estadístico de las medidas histométricas en relación al volumen de hueso neoformado en el interior de los defectos, revelo, a través del test de Tukey a un $5 \%$ de probabilidad, una diferencia estadísticamente significativa entre los grupos experimentales y el grupo control. Esto demuestra la importancia del relleno de los defectos con algún tipo sustituto para una reparación ósea con mayor cantidad y mejor calidad.

Cuando las medidas de los grupos experimentales fueron comparadas entre sí no hubo diferencia estadísticamente significante. of its low cost. ${ }^{14}$ Also its biocompatibilityy has been established scientifically as well as its osteoconductive properties. 14,18

Various investigation methods have been used that are aimed at evaluating the different materials that are being developed for aiding bone repair. According to Frame ${ }^{19}$ in 1980, the ideal animal for investigating bone grafts should be cheap, freely available and easy to handle. It should have an adequate area of cortical and spongy bone that permits repairing bone cavities that are large enough for investigation. In 1980 Frame, ${ }^{19}$ confirmed that rabbit calvarial skull bone is an excellent region for carrying out bone substitution studies that are to be used in the jaws, due to the similarity that exists between cranium rabbit bone and the human jaw. From and embrionary point of view they have the same intramembranous origin. Morphologically they are made up of two cortical bones separated by medullary bone and physiologically they have the same repair pattern. ${ }^{19}$ Kramer et al.20 (1968), showed that the main source of osteogenic cells is bone tissue in the defect margins, a fact that qualifies rabbit calvaria, as there is less periosteal interference than in other regions, in rabbits as well as other animals.

The use of critical defects (those where spontaneous bone repair is not able to fill the defect completely with bone tissue) in bone graft study models has relevant importance, as any new bone tissue formation occurring can be attributed to filling material. ${ }^{1,19} \mathrm{~A}$ complete study carried out by Frame ${ }^{19}$ in 1980 evaluated various diameters of cranial rabbit calvaria of the New Zealand breed and they observed that the cavities did not show signs of bone repair when these were larger than $15 \mathrm{~mm}$ in diameter. In this work $10 \mathrm{~mm}$ cavities were created, a size considered inferior to the critical size, but only in this way was creating two cavities in the same calvarium possible, one for the experimental group and the other for the control group. It should be pointed out that the various sacrifice times (4.7 and 15 weeks) made evaluating bone regeneration possible, should complete repair finally occur. The diameter used was also justified, as the main objective of the work was to compare regeneration between both bone substitutes, and not natural bone regeneration of rabbit calvarium.

The results demonstrated that at the end of the longest period before sacrifice, which was 15 weeks, spontaneous bone repair was not sufficient for encouraging complete bone regeneration between the borders of the control cavities. This confirms the results of various authors that agree that if the critical defect does not receive any specific treatment, and if spontaneous regeneration is allowed, complete bone regeneration will not take place. 10,22 In view of this, bone repair found in the experimental cavities of this work can be related to the filling of the cavities with demineralized bone matrix and castor bean oil polymer. Despite that the cavities used are not considered critical bone defects, these had a diameter that permitted the evaluation of the repair potential of the bone substitutes used. 
A pesar de que numéricamente, el grupo Polímero de Mamona había presentado una mayor media de formación que el Hueso Desmineralizado. Frente a estos resultados podemos suponer que, talvez una muestra mayor o un mayor control de las variables, posibilitaría una diferencia significativa.

En la regeneración ósea, el uso de sustitutos osteocondutores está contraindicada en la reparación de grandes defectos, debido a que la regeneración ósea con este tipo de material se limita a la periferia del implante. Por esto, es importante la combinación de una matriz osteocondutora con materiales osteoindutores, como los factores de crecimiento, para obtenerse una reparación ósea completa. ${ }^{26}$

\section{Conclusiones}

El uso de poliuretana derivada del aceite de mamona y la matriz ósea desmineralizada de origen humano mejoran el proceso de regeneración cuando lo comparamos a la regeneración ósea normal siendo que entre ambos materiales tuvieron un comportamiento similar sin diferencias estadísticas significantes entre sí.

\section{Bibliografía}

1. Taga R, Cestari TM, Silva TL, Stiipp CM. Reparo de defeito ósseo perene em crânio de cobaia pela aplicação de osseobond. Rev Bras Implant 1997;3:13-20.

2. Yamamoto $\Pi$, Kawakami M, Sakuda M. Defects of the rat premaxilla as a model of alveolar clefs for testing bone-inductive agents. J Oral Maxillofac Surg 1993;51:887-91.

3. Freeman E, Turnbull RS. The value of osseous coagulum as a graft material. J Periodont Res 1973;8:229-36.

4. Shigeyama Y, Dérrico JÁ, Stone R, Somerman MJ. Comercially-prepared allograft material has biological activity in vitro. J Periodontol 1995;66:478-87.

5. Ignácio $\mathrm{H}$, Mazzer $\mathrm{N}$, Barbieri $\mathrm{CH}$, Chierici $\mathrm{G}$. Uso da poliuretana derivada do óleo de mamona para prencher defeitos ósseos diafisário segmentares do rádio. Estudo experimental em coelhos. Rev Bras Ortop 1997;32:815.

6. Ota K. towards and ideal polyurethane graft for hemodialysis. / Biomater Appl 1989;4:141-57.

7. Henning E, John A, Zartnanack F, Lemm W, Bucherl ES, Wick G, Gerlach K. Biostability of polyurethane. Exp Chir Transplant Kunstliche Organe 1989;22:204.

8. Carvalho TL, Araújo CA, Teófilo JM, Brentegani LG. Histologic and histometric evaluation of rat alveolar wound healing around polyurethane resin implants. Int J Oral Maxillofac Surg 1997;26:149-52.

9. Piattelli A, Scarano M, Corigliano M, Piattelli M. Comparison of bone regeneration with the use of mineralized and demineralized freeze-dried bone allografts: a histological and histochemical study in man. Biomaterials 1996;17:1127-31.

10. Dupoirieux L, Costes V, Jammet P, Souyris F. Experimental study on demineralized bone matrix $(\mathrm{dbm})$ and coral as bone graft substitutes in maxillofacial surgery. Int J Oral Maxillofac Surg 1994;23:395-8.

11. Frota R. Avaliação histológica da reparação óssea na calota craniana de ratos utilizando enxerto de beta-tricálcio fosfato. 2003. 91f. Tese (Mestrado Em Odontologia) - Facultad de Odontología, Fop/Upe, Recife.

12. Alberius $P$, Klinge $B$, Isaksson $S$. Management of craniotomy in young rabbits. Lab Anim 1989;23:70-2.
In general we observed, through histological analysis, that the materials used positively influenced new bone formation in the defects, and quality and quantity improved when compared with the control group. In both experimental groups, osteoconduction was responsible for the repair. Demineralized bone showed behavior that was similar to that found by other authors in different works. 1,23

In order to make greater comparisons between the materials studied, histometric analysis, capable of quantifying new bone formation, was used. ${ }^{24,25}$

The statistical analysis of the histometric measurements in relation to newly formed bone volume in the interior of the defects, revealed through the Tukey test, a 5\% probability, a difference that was statistically significant between the experimental groups and the control group. This demonstrates the importance of filling the defects with some type of substitute in order to achieve bone repair of greater quantity and quality.

When the measurements of the experimental groups were compared, there were no statistically significant differences, despite that numerically the castor bean oil group had a greater mean formation than the demineralized bone group. Given these results, we can assume that, perhaps a greater sample or a greater control of the variables would make a significant difference possible.

In bone regeneration, the use of osteoconductive substitutes is contraindicated for the repair of large defects, due to bone regeneration with this type of material being limited to the periphery of the implant. Because of this, it is important to combine an osteoconductive matrix with osteoinductive materials, such as growth factors for obtaining complete bone repair. ${ }^{26}$

\section{Conclusions}

The use of polyurethane from castor bean oil and demineralized matrix of human origin, improve the regeneration process when compared with normal bone regeneration, as both materials showed similar behavior, without significant statistical differences among them. 
13. Alberius $P$, Isaksson $S$, Klinge $B$, Sjogren $S$, Jonsson J. Regeneration of cranial suture and bone plate lesions in rabbits. J Craniomaxillofac Surg 1990;18:179-271.

14. Ignácio H, Mazzer N, Barbieri CH, Chierici G. Estudos sobre a aplicabilidade médica da poliuretana derivada da mamona. Res Ortop 1996;2:10-5.

15. Buckley M. Bone Substitutes. En: Selected Readings In Oral And MaxiIlofacial Surgery, University Of Texas Southwestern Medical Center At Dallas, 1994. V. 4

16. Kamakura S, Sasano $Y$, Homa H, y cols. Implantation of octacalcium phosphate (ocp) in rat skull defedts enhances bone repair. J Dent Res 1999;78:1682-7.

17. Barbosa EP, Lima JH. C Ossoliofilizado - critérios para escolha com segurança. Rev Bras Implantodont 1996;2:17-8.

18. Garcia Junior IR. Avaliação experimental de três diferentes tipos de implantes: polímero de mamona, polietileno de alta densidade - medpor e matriz óssea bovina, no preenchimento de defeitos ósseos maxilares. Estudo histológico e histométrico em macacos. 2000. 73p. Tese (Doutorado) Faculdade De Odontologia De Araçatuba - Unesp, Araçatuba (Sp), 2000.

19. Frame JH. A convenient animal model for testing bone substitute materials. J Oral Surg 1980;38:176-80.
20. Kramer IR, Killey HC, Wright HC. A histological and radiological comparison of the healing of defects in the rabbit cavarium with or without implanted heterogenous anorganic bone. Arch Oral Biol 1968;13:1095-106.

21. Isaksson S, Alberius P. Comparison of regenerative capacity elicited by demineralized bone matrix of different embryonic origins. / Craniomaxillofac Surg 1992;20:73-80.

22. Rabie ABM, Lie Ken Jie RKP. Integration of endochondral bone grafts in the presence of demineralized bone matrix. Int J Oral Maxillofac Surg 1996;25:311-8.

23. Garcia RR. Comparação de matrizes ósseas desmineralizadas sobre o processo de regeneração óssea. Estudo histológico em calvária de coelhos. 1999;126p. Tese (Mestrado) - Faculdade De Odontologia De Piracicaba - Unicamp, Piracicaba(Sp), 2000.

24. Kleinschmidt JC, Marden LJ, Kent D, Quigley N, Hollinger JO. A multiphase system bone implant for regenerating the calvaria. Plast Reconst Surg 1993;91:581-8.

25. Lewandrowski KU, Bondre S, Gresser JD, Tomford WW, Wise DL, Trantolo DJ. Improved osteoconduction of cortical bone grafts by biodegradable foam coating. Biomed Mater Eng 1999;9:265-75.

26. Duguy N, Petite H, Arnaud E. Biomaterials and osseous regeneration. Ann Chir Plast Esther 2000;45:364-76. 